\title{
Research on the Formation and Development of Japan Express Industry
}

\author{
Jingxian Huang \\ Business Department \\ Guizhou Minzu University \\ Guiyang, China
}

\begin{abstract}
This paper analyzes the formation and development of Japan express industry from three aspects: personal express, commercial express and international express. In particular, this paper makes in-depth analysis on the express product of Yamato Transportation, innovation of express markets and the industrial competition between Yamoto Transportation and other competing companies.
\end{abstract}

$\begin{array}{rllr}\text { Keywords-personal } & \text { express; } & \text { commercial express; } \\ \text { international express; } & \text { industry formation; industrial }\end{array}$

\section{INTRODUCTION}

From the perspective of the logistics industry in Japan, courier service has constantly introduced innovative services and innovative products since its formation, and its business model is constantly being innovated. The innovation of logistics information system brought by the revolution of information technology has further promoted the innovative development of express business model.

\section{THE FORMATION AND DEVELOPMENT OF PERSONAL EXPRESS MARKET IN JAPAN}

\section{A. The Formation of Personal Express Market}

From the history of the development of small goods delivery in Japan, initially it is the postal parcel delivery service and the old national rail parcel shipping service that provide express service. At that time, users need to package the parcel exactly according to the requirements, and stick a postal label in accordance with the location rules. In addition, they need to carry the parcel to the station or post office themselves. In other words, this transport system is established in accordance with the theory of providing transport services, which is inconvenient for users. Yamato originally paid attention to this blue ocean area, and introduced the express service [Home delivery] from the perspective of express service users.

In the initial stages, emerging express service continued to seize market share of small parcels and national rail small

Soft Science Foundation Project of Guizhou Science and Technology Department, project number: science cooperation foundation of Guizhou [2017] 1515-6 Project Name: research on the innovative development of cross-border e-commerce. parcels. Then, the emerging express service quickly surpassed the size of the previous postal and national rail small goods transport market and drastically expanded the market. Looking through the entire transportation industry in Japan, from 1979 to 1985 , the growth rate of total freight volume was $-0.8 \%$ per annum. On the contrary, the express industry grew rapidly at a rate of $38.7 \%$ per annum. Express, a high degree of transport services tightly grasp the needs of consumers with its innovative services of [picking up by a phone, next-day delivery, a uniform cost] [2].

From the perspective of laws and regulations, under the influence of streamlining administration and delegating power prevailing in the world in 1990, [Second Law of Transportation] was established in Japan. The law of freight forwarding stipulated that the permit should be changed from an accreditation system to a licensing system and the transportation cost should be changed from the accreditation system to pre-application system. The growth of the express industry has brought the reform of the old legal system and promoted the introduction of a new legal system.

The success of the express business of Yamato Transportation really benefit from the business opportunities brought by reconditioning of environment like reorganization of expressway network and the improvement of IT technologies. However, the business opportunities brought by the environment are the same, so finding and accurately grasping the business opportunities is the decisive factor. The innovation of the courier service is also similar. At that time, what the president Masao Oshura of Yamato Transportation thinks about is personal delivery every day. As a result, the scenery he saw in Manhattan makes him think of the express service [Home delivery]. Such service like [Home delivery] can make profits after five years since the service was started, and then 35 competitors crowded in the industry. Since Yamato as a pioneer has opened a huge gap with other companies in the first five years, and become the innovator of express delivery business model, thus Masao Oshura becoming the leader of the operator [3].

\section{B. The Birth and Development of Yamato Transportation Express Service}

1) Success in short-distance transport and late start of long-distance transport: Yamato Transportation set up its headquarters in Kyobashi in Tokyo in 1919, and started the 
transportation business with 4 trucks. Yamato Transportation has established a transport network within the Kanto area before the World War II. By 1945, it had 151 vehicles and 500 employees, becoming the number one trucking company in Japan. However, the environment of post-war truck transport has undergone great changes. Highly economic growth brought about the improvement of road network, which makes long-distance transport gradually replace railway transport as a major force in the transport industry. At this time, Yamato Transportation obeys the transportation route within the Kanto area, without carrying out long-distance transportation in time. Afterwards, he finally applied for a route permit between Tokyo and Osaka in 1957 and got the permission in 1959. In 1960, he set up a branch in Osaka, which was five years later than other competitors in the industry.

2) Diversified and large cargo transport with low profitability: Yamato Transportation started late in the longdistance transport market, so it tried diversified ways to improve its operations. It has attempted many businesses such as freight forwarding, department store delivery, aviation, shipping, and packaging, but there was no improvement. What's worse, the benefits of truck delivery of commercial goods as the backbone business of the company have also started to deteriorate. Yamato Transportation refused small-sized goods with high cost and high expense to sign contracts with large cargo owner preferentially. Consequently, the profit margin is much lower than competitive enterprises.

3) To start to review personal express market: At this moment, President Masao Oshura with reverse thinking began to explore the possibility of individual-oriented delivery. At that time, the number of postal parcels was about 190 million pieces each year, and the number of railway parcels was about 60 million pieces each year, totaling 250 million. If 500 yen is a market of 125 billion yen, unclear breakeven point becomes the biggest worry.

4) A brainstorm in Manhattan: In 1973, President Masao Oshura went to the United States on a business trip and saw the scene of transport enterprise UPS allocating goods in Manhattan. The breakeven point of the logistics network is very important, and the truck unit also has a breakeven point. How many pieces of goods can be collected every day depends on the area of region that the truck takes charge. That is to say, if the cost of a truck and the number of goods the truck delivers one day can be calculated, the breakeven point can be calculated. At this time, Masao Oshura feels that courier business will be successful. After returning home, he put forward the ideas to relevant personnel of Yamato Transportation.

5) Start with 11 packages: In January, 1976, Yamato Transportation began its express business [Home delivery]. The number of goods handled on the first day was 11 . The total volume of goods in the year was 1.705 million. In 1977, 1978 and 1979, the total volume of goods was 5.4 million,
10.88 million and 22.26 million respectively. Then in 1981 and 1986, the number of goods reached 50.62 million and 230.99 million. Initially it provides services in 23 districts of Tokyo. 3 years later, it expanded to $27.4 \%$ of Japan's land area, $74.8 \%$ of the population. In 1980 , the number has already been equal to that of railroad parcels.

6) The participation of other competitors make the market competition intense: In the $1980 \mathrm{~s}$, due to the promising prospect of express market, other competitive companies began to take part, including 35 companies such as Sagawa Express and Nippon Express, making the market competition intensified. The next-day delivery began to expand in Japan, with express delivery offices increasing dramatically. The express market developed rapidly. In response to changes in the structure of the express delivery industry, Yamato Transportation continued to make innovations of new markets and new product in express business.

7) Fight with the administration: Around 1980, the business area of Yamato Transportation concentrated in Kanto area. When applying enlargement of business district, the issue of permission was postponed due to the opposition of transport ministry at the time and other transportation practitioners. In 1986, Yamato Transportation filed a lawsuit against the Minister of Transport at that time. At the same time, with the help of public opinion, the Ministry of Transport was prompted to issue the permission, and they expanded the business area, which laid the foundation for its future development.

8) Differentiation Strategy: Yamato Transportation has operated [3-year basic plan of operation] since 1981. It includes the completion of pavement of national express delivery network, expansion of the next-day delivery area, and establishment of operating system. With three threeyear plan, a total of nine years to complete the business plan makes the company's service network more convenient.

9) Centralized strategy: With the expansion of the express business, Yamato Transportation began to retreat from the previous commercial cargo transportation business.

10) Commercial strategy: The integration of hardware, software, and human resources establishes a new express business system to link receiving, transporting, and distribution systems, which improve the entire system.

11) New product development strategy: In 1983, it developed ski Home delivery; in 1984, golf Home delivery was developed; in 1986, it developed the Home delivery of home collection and refrigerated Home delivery in 1987 was developed. The development of new products of Yamato Transportation has created new markets and gained an overwhelming market share [4].

\section{EXPANSION AND DEVELOPMENT OF COMMERCIAL EXPRESS MARKET IN JAPAN}

Before 1990, it can be called [the establishment period of personal express market]. In this period of time, the 
development of commodities for personal express of Yamato Transportation was basically completed. In fact, the national express delivery network is basically completed. After 1990, the period of transformation from personal express to commercial goods came. In addition, the implementation of the [second Logistics Law] of the transportation industry in 1990 also became an iconic event.

\section{A. The Expansion of the Commercial Market}

The general characteristic of the logistics industry is the subordination of owner and ease of participation. In other words, it is very easy to enter the logistics industry, so it is difficult to form a difference, resulting in the formation of the buyer's market. In particular, with the simplification of power and decentralization initiated by the Second Logistics Act of 1990, the number of Japanese trucking companies increased by 1,500 companies annually over the 10 years, while the demand for the transport of goods decreased.

Personal express market of Yamato Transportation has low dependence on the owners, since the owner is dispersed and there is no subordination to the owners. More importantly, after a certain market size has been formed for the express of individual consumers, the low-attribute nature of the owner-subdivision has also been formed for the owners of bulk cargo such as the commercial cargo owner of department store.

Looking through the express delivery industry, after 1990, on the basis of personal express, the re-entry of commercial goods maintained the overall increase in the number of goods. During this period, Japanese economy was in a state of continuous downturn. The reason that almost all enterprises started to implement [lightness and thinning] also make the commercial cargo market become the source of goods for the express market. Enterprises began to reduce inventory, emphasize [necessary time, necessary goods, and necessary number], and the goods shipped by the enterprise become quite lightweight, with each of the goods less than $30 \mathrm{~kg}$, so it naturally became the object of express service. Besides, the requirements of shortening the procurement time make the next-day delivery and appointed-time delivery services become essential. Therefore, after the 1990s, the express delivery industry still maintained a sustained and rapid growth.

\section{B. Participation of Sagawa Express and Leap of Online Shopping}

In 1998, two incidents signified that the superiority of Yamato Transportation might be shaken: participation and rapid growth of Sagawa Express and the emergence of largescale consignors caused by the development of online shopping.

1) Participation of Sagawa express: As mentioned above, Yamato Transportation has started to enter the commercial cargo filed from personal express market, which is exactly what Sagawa Express does best in. 70\% of the consignors of Yamato Transportation after 1990 are the owners of small commercial goods. This also prompted
Sagawa Express to enter the field of express. At the same time, Sagawa Express explained that [so far, the transportation costs system of various branches of Sagawa Express is variant. Entering into the field of express can make the system of transportation costs clearer]. Since small commercial goods less than $30 \mathrm{~kg}$ have always been the strong areas for Sagawa Express, so the performance of Sagawa Express grew rapidly after it entering the field of express and the total amount of cargo quickly approached that of Yamato Transportation [5].

2) Leap of online shopping: The rapid development of online shopping and traditional online shopping and the rapid popularization of new business models such as direct delivery from production place, the online retail industry has two sides influence on the express industry. On the one hand, the number of small items has increased. On the other hand, the bargaining ability of the express delivery industry has been enhanced due to the relatively high density of small items in the online retail industry. Express market entered the two-giant era from the era of one-giant Yamato Transportation, and the substitutability of express companies has increased.

\section{C. "The Era of the Hegemony of Three Kingdoms" of Express Market}

According to the data of Ministry of Land, Infrastructure and Transport of Japan in 2012, the market share and the total number of express delivery of Yamato Transportation were $42.7 \%$ and 1.48754 billion respectively; that of Sagawa Express was 1.35651 billion with a market share of $38.9 \%$. The number of Japan postal service was 382.21 million with a market share of $10.9 \%$ [6].

Japan Post Group has 24,000 post offices in Japan, 180,000 mailboxes. So rich logistics network assets now only occupy $11 \%$ of the market share, and there is still a big gap between the number one of express delivery industry Yamato Transportation and the number two Sagawa Express. In order to seize the express market share, Japan Post Group acquired express delivery business of Japan Express in 2010. In addition, Japanese politics promoted the privatization of the Japanese postal group and in 2015, Postal Co., Ltd. went public under the lead of current president Takahashi [7].

Japan Post Group, in the face of rapidly growing express market, began to use their own advantages to start counterattack, and express market of Japan has entered the era of the hegemony of three kingdoms.

\section{D. "Warring States Period" of Express Market was Kicked off}

In the melee of top three express services companies, the situation of gekokujo also appeared. In 2014, 25 online retail enterprises joined together to form the "express seminar" to share information and seek common development. Although all enterprises are small in size, the combined quantities of more than 100 million goods a year cannot be ignored. In addition, since 2012, Sagawa Express started large cargo transportation service. In addition, a number of Japanese 
convenience stores began to enter the express logistics industry [8].

From the era of two giant, express market entered the era of the hegemony of three Kingdoms due to the start of express service of postal service and now it actually entered the Warring States period of express industry.

\section{THE FORMATION AND DEVELOPMENT OF JAPAN INTERNATIONAL EXPRESS}

Japan international express was born in 1979 and rapidly developed as part of the internationalization of American express enterprises.

\section{A. International Document Express}

The original air cargo is transported from the airport to the airport. With the improvement of pick-up delivery system, clearance procedures and the preparation of cargo tracking system, a more advanced door-to-door delivery service has become possible. The goods in the first stage of development of international express delivery are the previous air transport shipping documents. Initially, international documents express is delivered by messenger. The object of international documents is the shipping documents, contract documents, catalogs, design drawings, and business documents and so on. The weight is about below $1 \mathrm{~kg}$, which can be said to play the role of information transfer.

\section{B. International Small Parcel Delivery}

From the perspective of circulation function of international parcel function, the general aviation cargo sent out from Japan is semi-finished electronic products and mechanical components. These goods can afford higher shipping costs because of their higher added value. In addition, international parcel also includes the supplementary transportation of ordinary transport of international goods such as emergency transport or the transport of goods samples. Therefore, compared with the general international air cargo of $150 \mathrm{~kg}$, the average weight of international parcels is $50-60 \mathrm{~kg}$.

Since then, with the internationalization of Japanese consumers' lives, the demand for [buying goods from the world in their own homes] has increased. Japan Ministry of Transport proposed to establish a door-to-door international small parcel delivery service system. After 1988, department stores began to unite with international express delivery companies and launched such import-oriented businesses. In order to promote the utilization of international express, enrich the purchasing channels of goods, and promote the trade balance and reform of economic structure, Japan government actively implemented corresponding policies.

In addition, overseas travelers of 10 million each year also began to mail local souvenirs through international express. International express as a way to reduce carry-on luggage seizes the traveler's needs, and is widely popularized as a convenient service [9].

\section{Solutions for International Express Logistics}

Since 1998, Japan Express and FedEx joined to enter the international market. The biggest reason for such a wave of consolidation is the changes in need for logistics. High-end manufacturers such as automobiles, computers, communications equipment, precision machinery, and various electronic products have undergone the development of globalization and multi-nationalization and need to conduct the production of manufactured parts dispersedly around the world. All kinds of spare parts need to be crossproduced in factories all over the world to produce finished product. At the same time, the cost of warehousing need to be reduced and the delivery time need to be ensured. Therefore, the high capability of logistics with few batches and high frequencies is necessary. In this context, highquality transport management business model like thirdparty logistics and supply chain management was born. [10]

Express delivery companies also began to prepare logistics centers across the country to provide comprehensive logistics services. Express has gradually developed from the customer-to-customer as the center to business-to-business and business-to-customer service, and continued to maintain this rapid growth [11]. For example, Yamato Transportation also started to open international express business in Shanghai, Singapore, Hong Kong and Malaysia [12]

\section{CONCLUSION}

To sum up, the company that originally introduced personal express service in Japan is Yamato Transportation. With changes in the Japanese logistics industry, Yamato Transportation began to enter the commercial express delivery field and unfolded fierce competition with Sagawa Express in this area. Recently, Japan Post also began to use its own advantages to carry out express business. At the same time, convenience stores in Japan and other companies also joined the competition of express business.

The development of Japan international express is developed as a part of the internationalization of American express enterprises. The initial international express delivery business was for documents, and later international small parcel delivery rapidly developed under the influence of the environment of internationalization of enterprises. Express companies in Japan began to layout the international express network, and then world's express companies began to enter the field of logistics solutions, and launched a new fierce competition.

\section{REFERENCES}

[1] Masaru Udagawa, Jun Ikishima. "Pioneer of new service industry"Japanese management history learning from entrepreneurs. Yuwakaku books, 2011: 309.

[2] Minoru Saito. Home delivery - innovator of modern transport. Seiyado bookstore, 1991: 71-76.

[3] Kenji Takahashi. Innovation was born in this way: innovation case seen from digital camera and home delivery. Management sensor, 2006. 6: 19.

[4] Masao Ogura. Ogura Masao's Business Administration. Nikkei BP Inc. 1999. 
[5] Katsuyuki Ozawa. Trends of the parcel delivery market since the 1990s. International Comparative History of Distribution System. Bunsho-do, 2004: 276-277.

[6] Homepage of Ministry of Land, Infrastructure and Transport.

[7] Homepage of Japan Post group. I can not deliver it, I will not deliver it! courier's rebellion. weekly magazine diamond, 2014, 7.5: 35 .

[8] Katsuhiro Yamaguchi. The fast-growing international courier market. transport. 1991. 5: 35-36.

[9] Feature: How long will the large-scale cooperation boom and betting on responding to changing logistics needs, larger and stronger. SPACE, 2002.2: 8 .

[10] Toshinori Nemoto, Katsuhiko Hayashi. Home delivery service supports online shopping. ed: Toshinori Nemoto. Study on construction of transportation network in express business. Seminar of Japan Transportation Policy, 2013: 9-10.

[11] Overseas study of Japan External Trade Organization (JETRO). Study on the international development of service industry: Yamato Transport Co., Ltd. (overseas: China). JETRO, 2012.3:1. 